NASA/TM—2014-218108

\title{
Updates to Simulation of a Single-Element Lean-Direct Injection Combustor Using a Polyhedral Mesh Derived From Hanging-Node Elements
}

Changju Thomas Wey and Nan-Suey Liu

Glenn Research Center, Cleveland, Ohio 


\section{NASA STI Program . . . in Profile}

Since its founding, NASA has been dedicated to the advancement of aeronautics and space science. The NASA Scientific and Technical Information (STI) program plays a key part in helping NASA maintain this important role.

The NASA STI Program operates under the auspices of the Agency Chief Information Officer. It collects, organizes, provides for archiving, and disseminates NASA's STI. The NASA STI program provides access to the NASA Aeronautics and Space Database and its public interface, the NASA Technical Reports Server, thus providing one of the largest collections of aeronautical and space science STI in the world. Results are published in both non-NASA channels and by NASA in the NASA STI Report Series, which includes the following report types:

- TECHNICAL PUBLICATION. Reports of completed research or a major significant phase of research that present the results of NASA programs and include extensive data or theoretical analysis. Includes compilations of significant scientific and technical data and information deemed to be of continuing reference value. NASA counterpart of peer-reviewed formal professional papers but has less stringent limitations on manuscript length and extent of graphic presentations.

- TECHNICAL MEMORANDUM. Scientific and technical findings that are preliminary or of specialized interest, e.g., quick release reports, working papers, and bibliographies that contain minimal annotation. Does not contain extensive analysis.

- CONTRACTOR REPORT. Scientific and technical findings by NASA-sponsored contractors and grantees.
- CONFERENCE PUBLICATION. Collected papers from scientific and technical conferences, symposia, seminars, or other meetings sponsored or cosponsored by NASA.

- SPECIAL PUBLICATION. Scientific, technical, or historical information from NASA programs, projects, and missions, often concerned with subjects having substantial public interest.

- TECHNICAL TRANSLATION. Englishlanguage translations of foreign scientific and technical material pertinent to NASA's mission.

Specialized services also include creating custom thesauri, building customized databases, organizing and publishing research results.

For more information about the NASA STI program, see the following:

- Access the NASA STI program home page at http://www.sti.nasa.gov

- E-mail your question to help@sti.nasa.gov

- Fax your question to the NASA STI Information Desk at 443-757-5803

- Phone the NASA STI Information Desk at 443-757-5802

- Write to: STI Information Desk NASA Center for AeroSpace Information 7115 Standard Drive Hanover, MD 21076-1320 
NASA/TM-2014-218108

\section{Updates to Simulation of a Single-Element Lean-Direct Injection Combustor Using a} Polyhedral Mesh Derived From Hanging-Node Elements

Changju Thomas Wey and Nan-Suey Liu

Glenn Research Center, Cleveland, Ohio

Prepared for the

SciTech 2014

sponsored by the American Institute of Aeronautics and Astronautics

National Harbor, Maryland, January 13-17, 2014

National Aeronautics and

Space Administration

Glenn Research Center

Cleveland, Ohio 44135 
This report is a formal draft or working paper, intended to solicit comments and ideas from a technical peer group.

This report contains preliminary findings, subject to revision as analysis proceeds.

This work was sponsored by the Fundamental Aeronautics Program at the NASA Glenn Research Center.

Level of Review: This material has been technically reviewed by technical management.

Available from

NASA Center for Aerospace Information 7115 Standard Drive

Hanover, MD 21076-1320
National Technical Information Service 5301 Shawnee Road Alexandria, VA 22312

Available electronically at http://www.sti.nasa.gov 


\title{
Updates to Simulation of a Single-Element Lean-Direct Injection Combustor Using a Polyhedral Mesh Derived From Hanging-Node Elements
}

\author{
Changju Thomas Wey and Nan-Suey Liu \\ National Aeronautics and Space Administration \\ Glenn Research Center \\ Cleveland, Ohio 44135
}

\begin{abstract}
This paper summarizes the procedures of inserting a thin-layer mesh to existing inviscid polyhedral mesh either with or without hanging-node elements as well as presents sample results from its applications to the numerical solution of a single-element LDI combustor using a releasable edition of the National Combustion Code (NCC).
\end{abstract}

\section{Introduction}

The lean direct injection (LDI) concept has the potential for low emissions under operational (compression ratios up to 60:1 and peak temperature $3000^{\circ} \mathrm{F}$ ) conditions. For a LDI combustor, most of the air directly enters the combustor through the swirler. In this concept, the liquid fuel is injected from fuel injectors directly into the incoming swirling airflow, and the swirling air stream is used to atomize the injected liquid as well as to promote fuel-air mixing. The flame structure can be very complex and locally range from non-premixed to premixed burning.

Recently, a single-element LDI combustor experiment has been used as a test bed for assessing, further developing and validating the capability of two-phase turbulent combustion modeling and simulation. This combustor consists of an air passage with a $60^{\circ}$ six-bladed air swirler, a convergingdiversion section and a chamber with a square cross-section. The fuel is injected through the center of the swirler and exit at the throat of the venture.

A series of numerical calculations have been performed by using (1) the time filtered Navier-Stokes (TFNS) methodology and (2) the large eddy simulation (LES) methodology. The sub-grid models employed for turbulent mixing and combustion include the well-mixed model, the linear eddy mixing (LEM) model; the Eulerian filtered mass density function (EUFDF/EUPDF) model, and the flameletbased model. Results from these methodologies invoking various sub-grid models are summarized in Reference 1, and a more detailed description of the TFNS approach can be found in Reference 2. It should be pointed out that TFNS is not LES, nor hybrid RANS/LES, nor, in general, unsteady Reynoldsaveraged Navier-Stokes (URANS). Like the LES, TFNS is capable of capturing the dynamically important, unsteady turbulent flow structures, even when RANS-grade meshes are used. Unlike the LES, the grid resolution and the turbulence model fidelity are not formally linked, therefore, in principle; a grid independent solution can be unambiguously attained in the TFNS approach.

Species transport equation in the multiple rotating frames of reference (MRF) is written as:

$$
\frac{d}{d t} \iiint_{V} \rho_{m} d V+\iint_{A} \rho_{m}\left(\vec{u}-\vec{U}_{g}\right) \cdot d \vec{A}=\iint_{A} \rho D_{e f f} \nabla\left(\frac{\rho_{m}}{\rho}\right) \cdot d \vec{A}+\iiint_{V} \dot{w}_{m}^{\prime \prime \prime} d V+\iiint_{V} S_{m l s} d V
$$

\footnotetext{
$\dot{w}_{m}^{\prime \prime \prime}$, the production rate of species $m$ per unit volume, is the main source of the turbulence-chemistry interaction. The sub-grid, turbulence-chemistry model, either the linear eddy mixing (LEM) or the Eulerian filtered mass density function (EUFDF/EUPDF) model, needs finer volume lumps or Monte Carlo particles been generated for each CFD cells for entire domain as illustrated in Figures 1 and 2.
} 


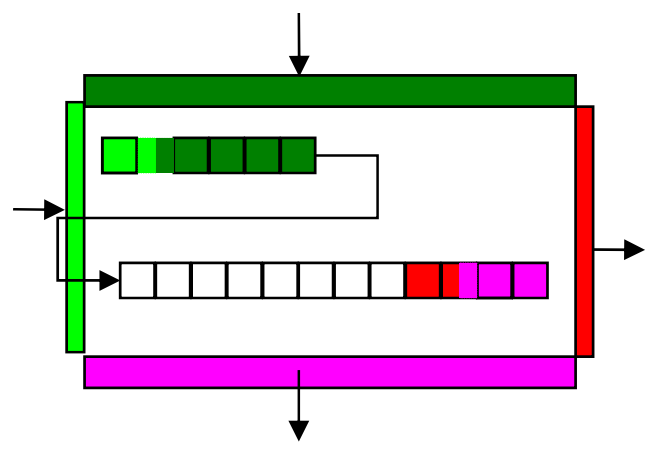

Arrows-Convection direction

Initial number of lumps-12

Light Green-inward mass (1.5)

Dark Green-inward mass (4.5)

Red-outward mass (1.5)

Magenta-outward mass (2.5)

Current number of lumps-14

Final number of lumps will became 12 after

re-gridding via equalizing the volume.

Figure 1.-Schematic illustrating the splicing algorithm used for scalar convection. (Assuming number of LEM lumps is 12. Each lump contains volume and species density).

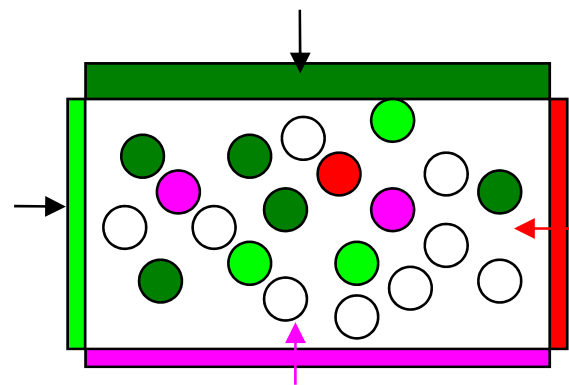

Figure 2.-Schematic illustrating the process of the scalar convection and diffusion for the Eulerian scalar Monte Carlo FDF/PDF model.

Both of the turbulence-chemistry sub-grid models mentioned above does not solve components of the momentum in the sub-grid elements or particles. In addition to the physics-based sub-grid models for the entire domain, an adaptive mesh-based sub-grid model was developed and implemented recently.

In previous work (Ref. 3), a mesh-based enhancement for the scalar mixing was proposed. It was speculated there that greater number of the flux-exchange between solution elements, i.e., using polyhedrons as control volumes, may have the potentials to enhance the mixing of the scalar for the modeling of the turbulence-chemistry interaction. In Reference 3, a honey-comb like polyhedral mesh was generated from a regular unstructured mesh, which could be the combinations of tetrahedrons, hexahedrons, prisms and pyramids, through the processes of refinement, reconnection and agglomeration.

In Reference 4, a polyhedral mesh is generated or more precisely post-processed from a set of hanging-node or conforming unstructured mesh. A LDI combustor mesh refined from a set of allhexahedral mesh is shown in Figure 3 with the temperature as the indicator for the criterion of refinement.

In Figure 4, the region of the refinement is identified by prescribing the desired location. Those subgrid refinements are done in all directions for the selected cells. For the cases of high Reynolds number flows, the sub-grid refinements normal to wall are desirable and necessary. In the present work, a thinlayer, normal to wall refinement scheme is developed. It is well known that inviscid tetrahedral mesh or hanging-node mesh, such as Cartesian mesh, can be generated very quickly with minimal user interfaces. They are ideal for the rapid prototyping of the combustor geometry. However in most of cases, those meshes are not suitable for the high Reynolds number turbulent flows due to lack of well-behavior layer mesh near the walls. Even in the conceptual design stages of the combustors, the viscous effects of the solid walls should be treated as one of the design variables. 


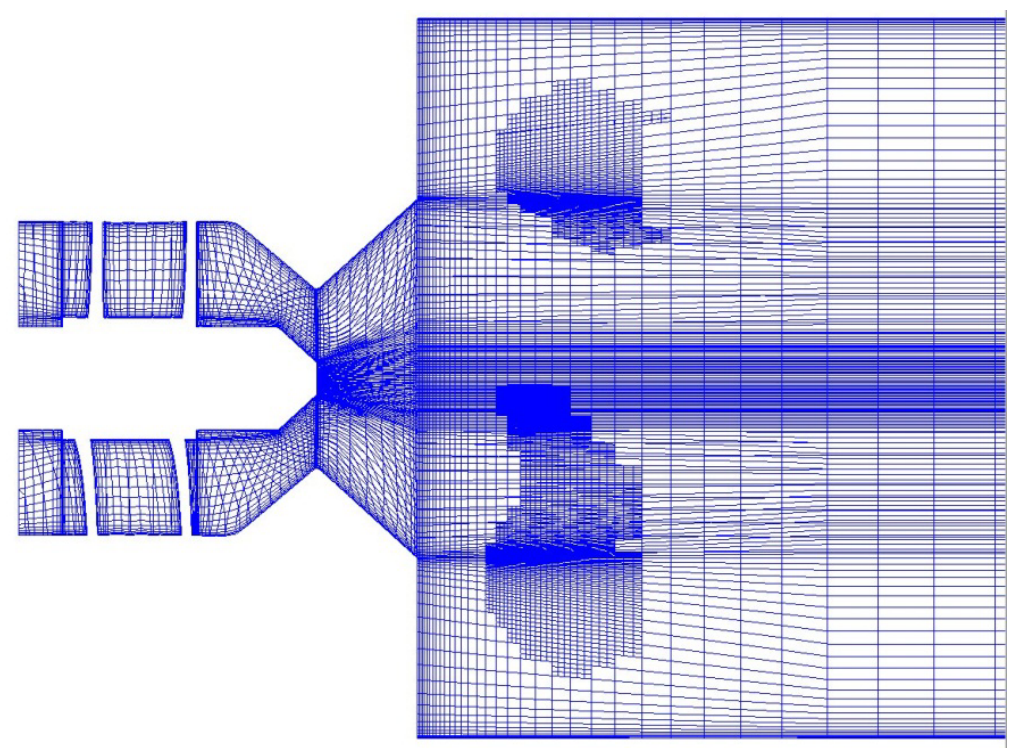

Figure 3.-A plane cut of polyhedrons around the mid-plane of the combustor with the temperature as the criterion scalar for refinement.

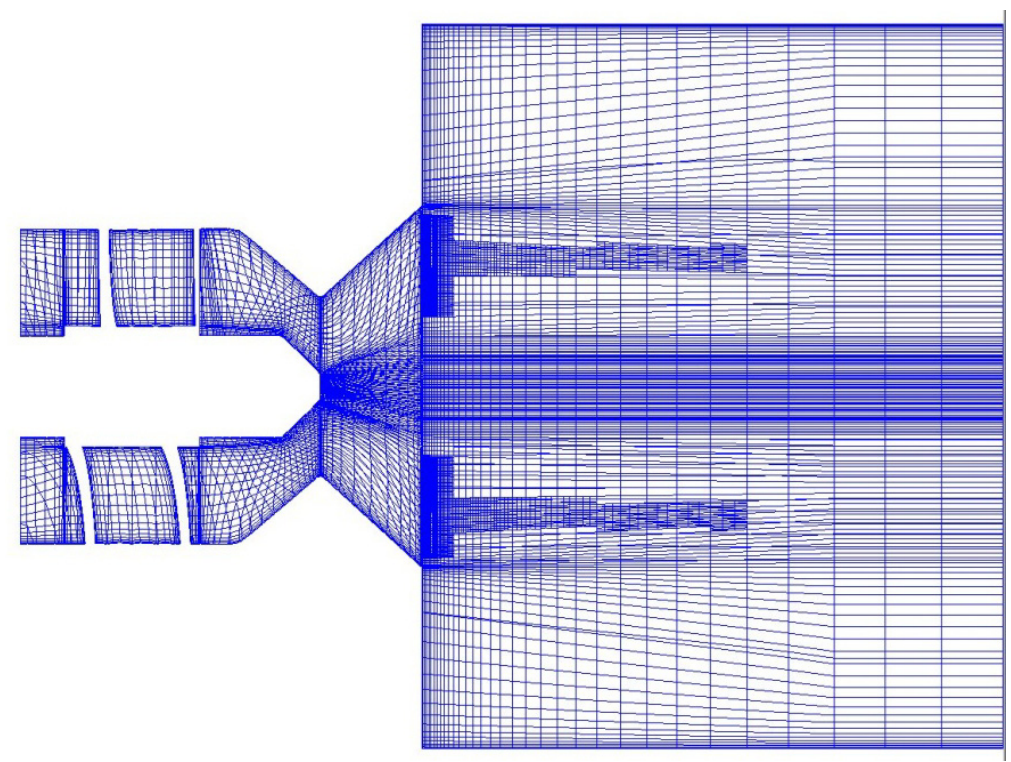

Figure 4.-A plane cut of polyhedrons around the mid-plane of the combustor with specified region refined. 


\section{Generation of a Thin Layer Grid Normal to the Wall Boundary of an Inviscid Mesh}

A set of inviscid cells that represents a LDI combustor is shown in Figure 5. The process starts by identifying each node's level of connectivity from the wall for the entire mesh. The nodal level of connectivity from the wall will be used later to determine the sequence of the displacement of the grid nodes. There is an analogy between the nodal level of connectivity of an unstructured grid and $K=$ constant surfaces of an $I^{*} J^{*} K$ structured grid. For example a plane cut through the center of an inviscid mesh representing a LDI combustor geometry is shown in Figure 3. In Figure 6, iso-surfaces of level of connectivity of the nodes in the center of the combustor are shown.

The next step will be marching-grid generation from the wall boundary of the mesh. The original method of the marching grid generation was described in Reference 5. The process will be described here very briefly. Determination of marching distances per layer is based on the rate of area change due to surface virtual offset. It yields relatively large marching steps in the convex regions where dihedral angle is less than $180^{\circ}$, and small steps in the concave regions where dihedral angle is larger than $180^{\circ}$.

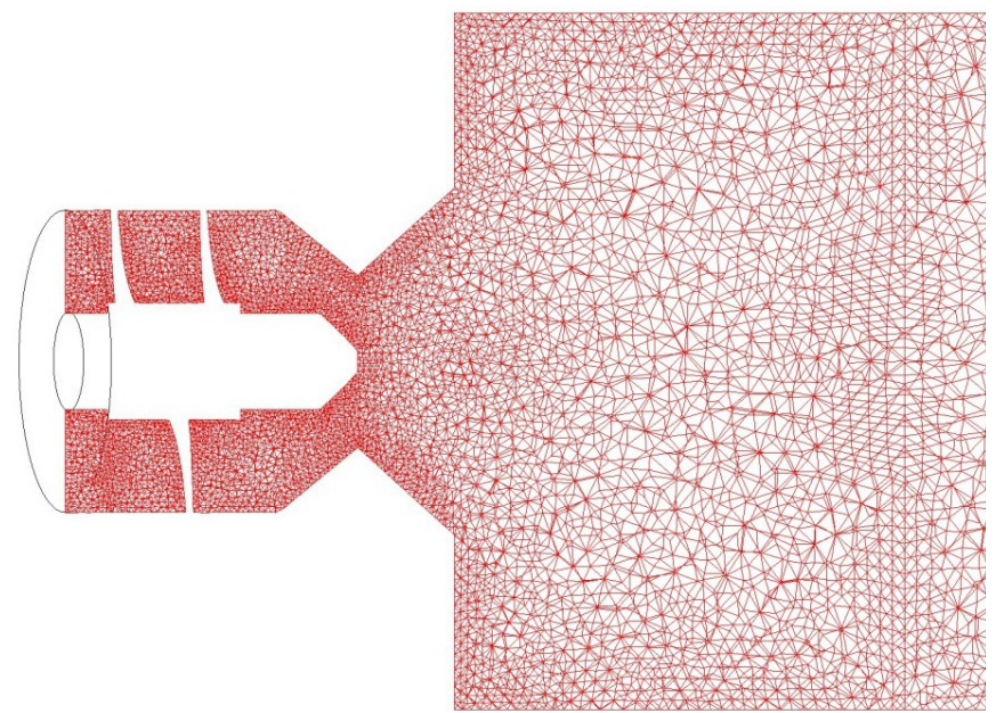

Figure 5.-A plane cut of an inviscid all-tetrahedral grid around the mid-plane of the combustor.

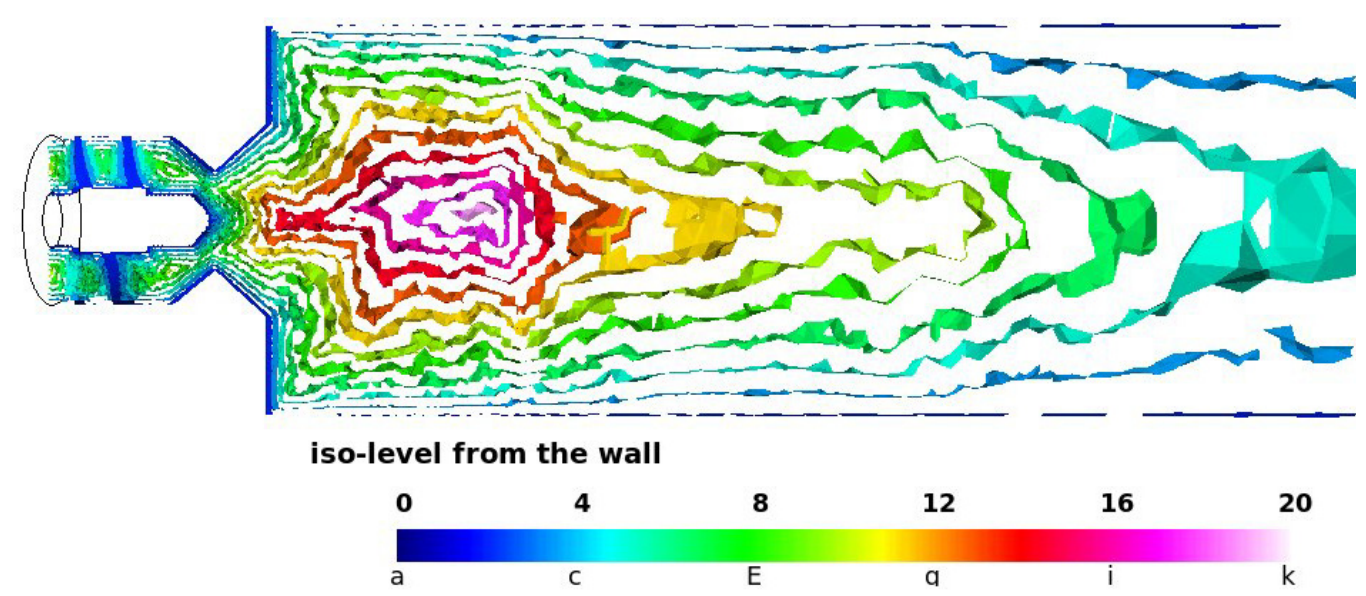

Figure 6.-Iso-surfaces of nodal level of connectivity from the wall in the center of the combustor to be used for the orderly deformation of the mesh. 
The surface nodes are divided into two groups, one is the grid points with larger rate of area change due to surface virtual offset, and the other is the grid points with smaller rate of area change due to surface virtual offset. The former group will be marching first.

The initial marching vectors are the normal vectors. However, this may not provide a valid grid since the grid lines may intersect each other in the convex regions.

To prevent intersection, the weighted Laplacian type smoothing operation is applied to the components of the marching vectors. The weighting function is also based on the rate of area change due to surface virtual offset. The grid points in latter group will be marching after the first group. The marching vectors are constraint by the marching direction of the first group.

The resulting grid is a set of semi-structured, distinct layer grid. It will be the source of the deformation for the inviscid grid. The process starts by inserting the semi-structured grid from the user selected layer upward.

Previous computed levels of nodal-connectivity for the inviscid grid is used to guide the deformation of the mesh in such order that the grid points of level one is displaced first, the grid points of the level two is displaced second, and so on. To reduce the tangling of the mesh, spring analogy is applied to each edge of the mesh. That is that each edge of the inviscid grid is modelled as a tension spring. The spring constant is defined as the inverse of the length of the edge. The displacements of the grid points are adjusted for individual level initially. After the grid points have been deformed on current level, the displacements of the grid points will be conveyed into edge displacements in which they become the nodal displacement on next level. Once all the layer grid points have been inserted, the entire network of springs of the inviscid grid will adjusted again to untangle and smooth the grid. In Figure 7, it is shown that a cell-cutting body-captured inviscid mesh is refined and to be able to handle high Reynolds number turbulent flow. A node-blanking body-captured inviscid mesh with the inserted thin-layer refined mesh is depicted in Figure 8.

For the case of LDI combustor shown in Figures 5 and 6, a thin-layer refined grid is generated between solid wall and the inviscid all-tetrahedral mesh. The result is shown in Figure 9. An expanded view near the corner of a swirler blade is shown in Figure 10. The former grid consists of 1,554,419 tetrahedrons, 283,200 nodes. The latter grid consists of 2,593,215 cells (tetrahedrons and prisms) and 803,852 nodes which is a whopping 67 percent increase in cell count. It demonstrates that a typical turbulent flow simulation costs much more than an inviscid flow analysis.
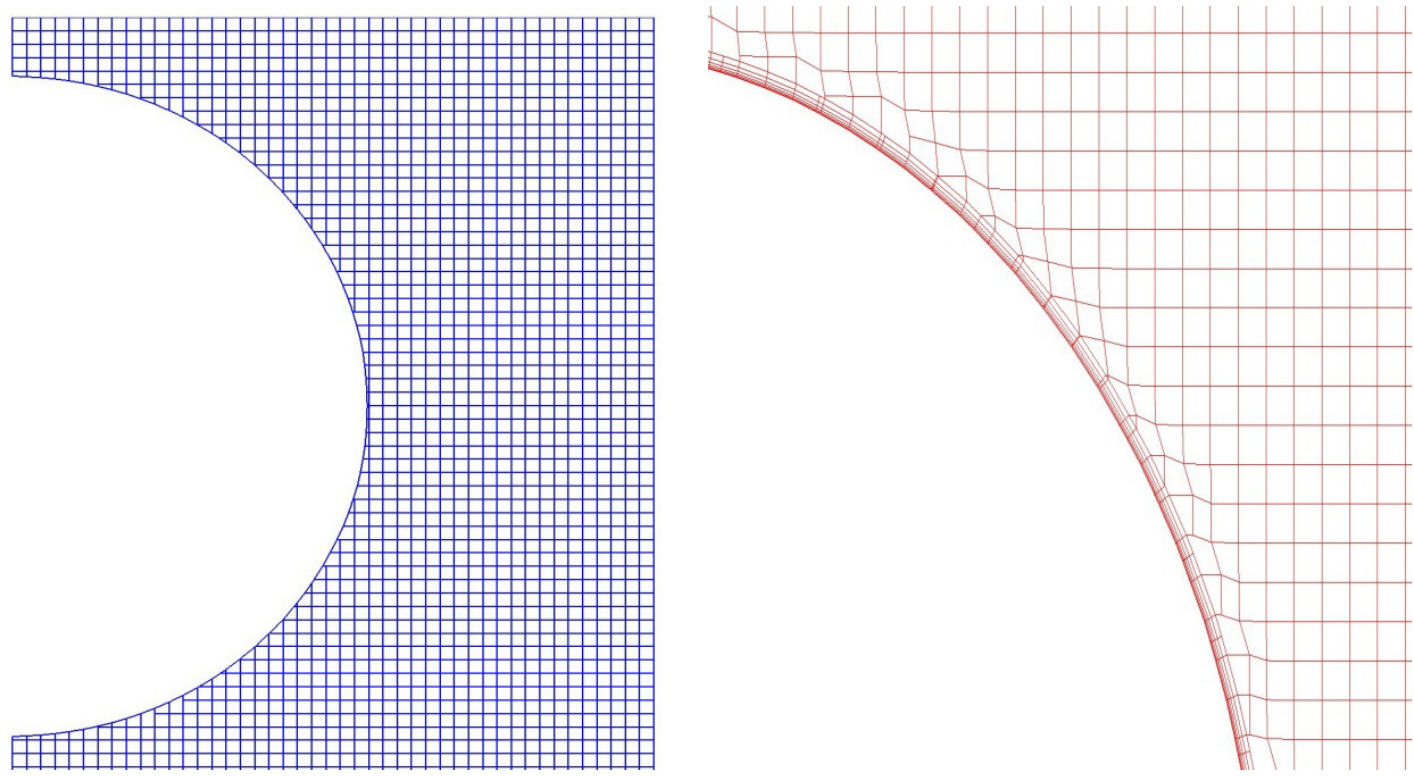

Figure 7.-Left: a cell-cutting inviscid mesh; right: a thin-layer refined grid merged with original grid. 


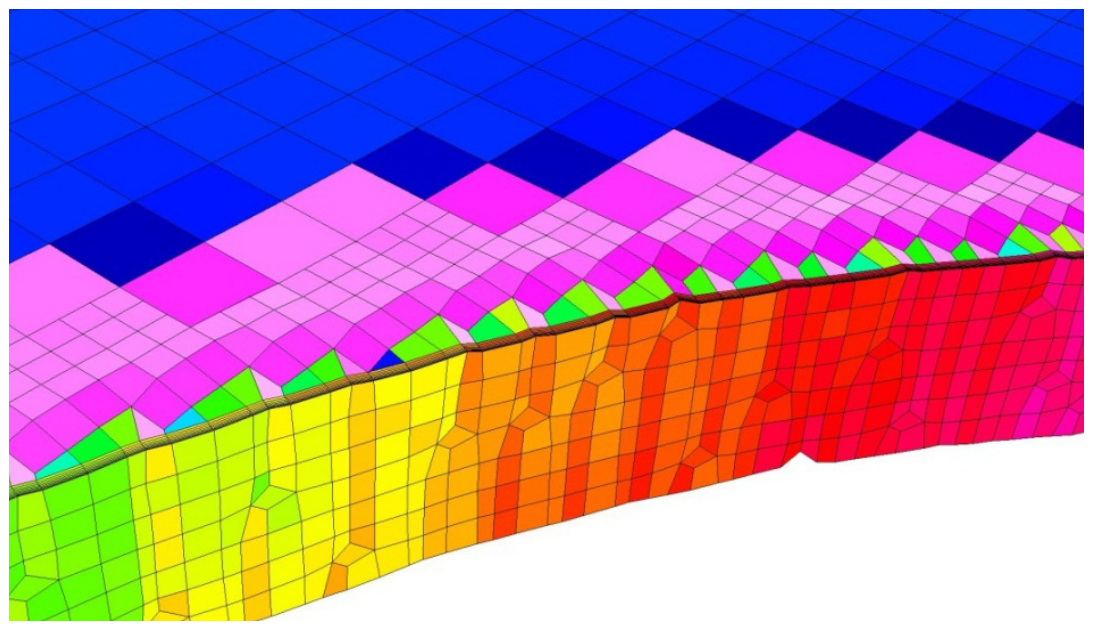

Figure 8.-A node-blanking body-captured viscous grid.

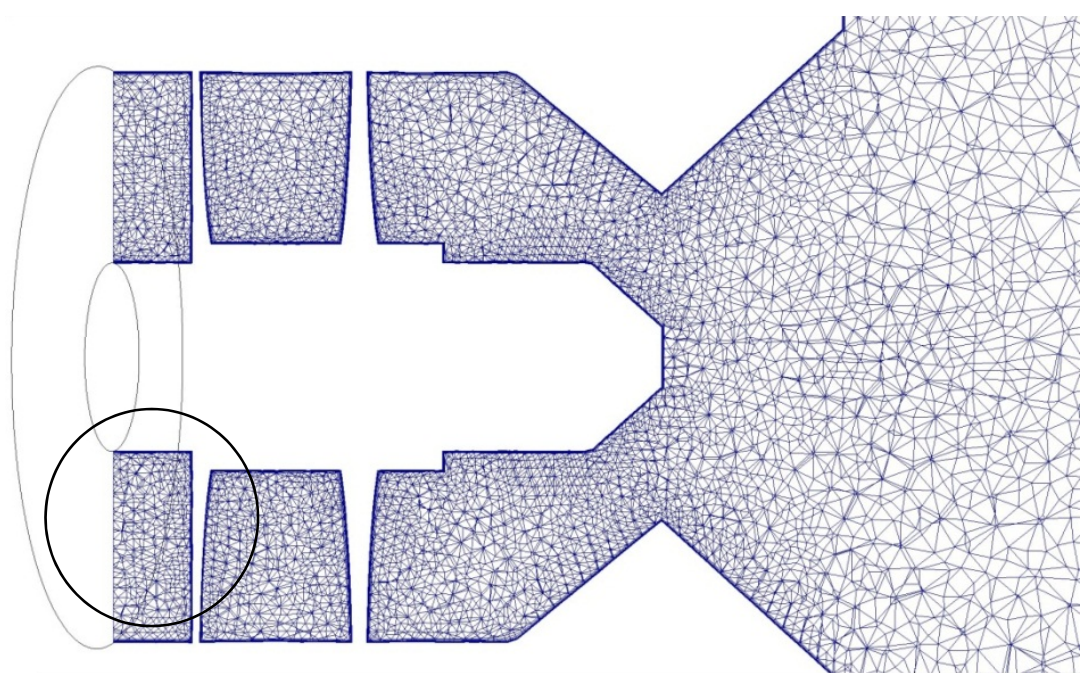

Figure 9.-A thin-layer refined grid is generated between solid wall and the inviscid all-tetrahedral mesh. The final mesh mounts to a whopping 67 percent increase of cells.
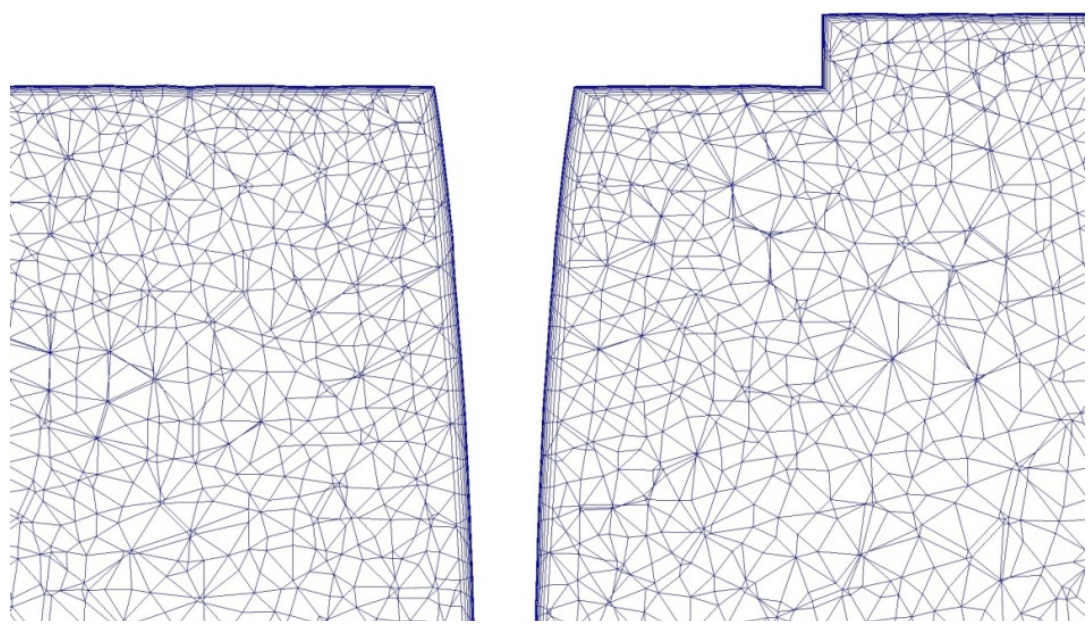

Figure 10.-An expanded view near the corner of a swirler blade; There are 12 extra layers are inserted into the original grid. 


\section{Sample Applications of Hanging-Node Polyhedral Meshes}

A hybrid prism and tetrahedron mesh describing a single-element LDI combustor is selected for the purpose of demonstration. This combustor consists of an air passage with a $60^{\circ}$ six-bladed air swirler, a converging-diversion section and a chamber with a square cross-section. The fuel is injected through the center of the swirler and exit at the throat of the venture. The original mesh contains consists of 2,593,215 cells (tetrahedrons and prisms) and 803,852 nodes.

Three meshes are adaptively generated by selecting, (1) temperature; (2) unburned hydrocarbon (UHC); (3) fuel-vapor just right after evaporated, of the field solutions as the criterion for refinement. The first grid consists of 2,783,673 polyhedrons, 992827 nodes and a center plane cut is shown in Figure 11. The second grid consists of 2,632,317 cells and 840,482 nodes. A center plane cut is shown in Figure 12. The third grid consists of 2,636,377 polyhedrons, 844,422 nodes and a center plane cut is shown in Figure 13. The number of solution elements is compatible between these three grids.

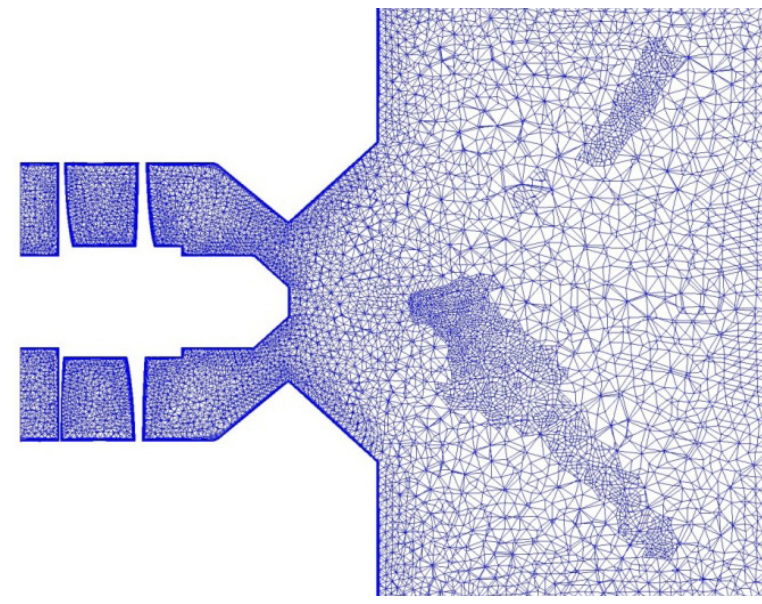

Figure 11.-Temperature-based refined grid. (2783673 cells).

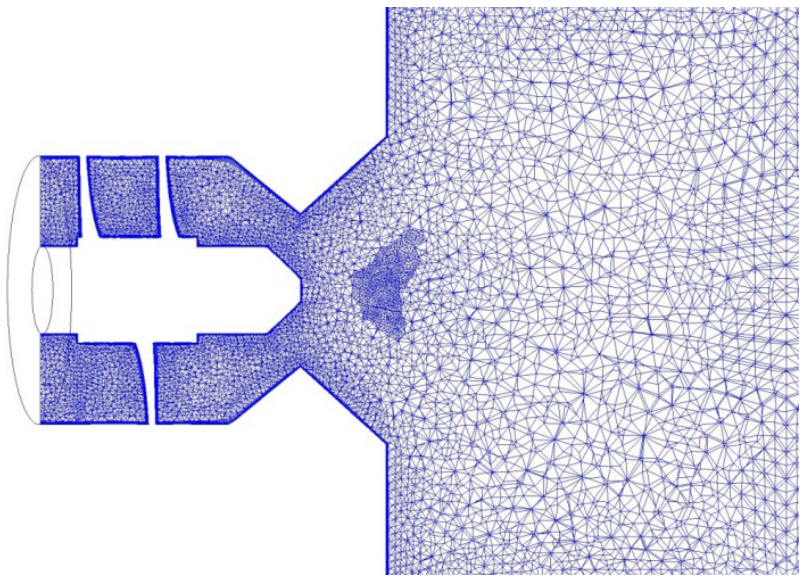

Figure 12.-UHC-based refined grid. (2,632,317 cells).

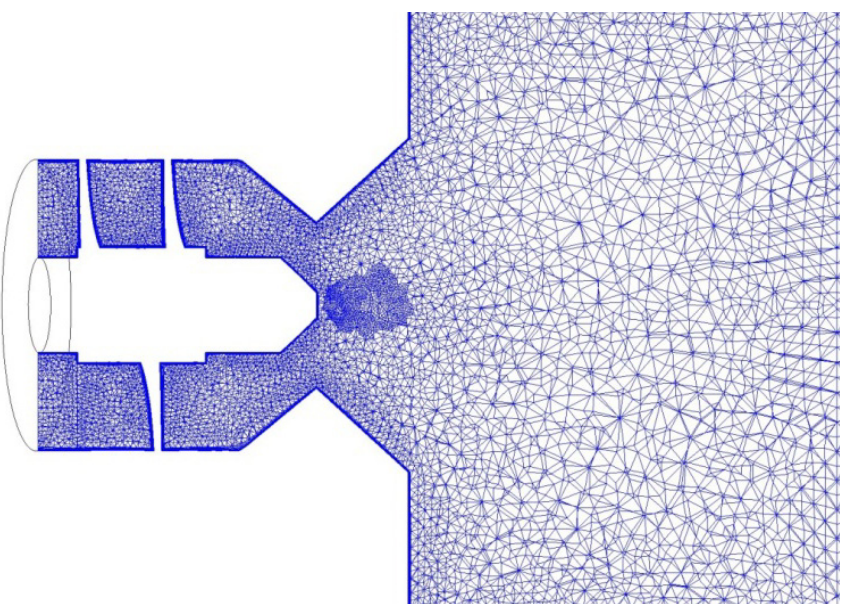

Figure 13.-Fuel droplet vapor-based refined grid. (2,636,377 cells). 


\section{Preliminary Results}

\section{Nonreacting Case}

At the inlet of the swirler, the inflow velocity, the static temperature and the density of the gas phase are specified as $20.14 \mathrm{~m} / \mathrm{s}, 294.28 \mathrm{~K}, 1.19 \mathrm{~kg} / \mathrm{m}^{3}$, respectively. At the outflow boundary, the static pressure is imposed at $101325 \mathrm{~Pa}$. The generalized wall function is applied to solid wall boundaries. The thermal boundary condition for all the solid surfaces of the combustor is set to adiabatic. Two sets of mesh are selected for this case, one is shown in Figure 5 which is all-tetrahedron inviscid grid, and the other is shown in Figure 9 which is a hybrid prism and tetrahedron grid. The RANS cubic turbulence model is used for both meshes. In Figure 14, the contours of the axial velocity in the center plane of the geometry in the upper panel are computed from inviscid mesh, while that of the viscous mesh is shown in the lower panel. The velocity pattern is quite different near the exit of the swirler cup. In Figure 15, the contours of the static pressure in the center plane of the geometry in the upper panel are computed from inviscid mesh, while that of the viscous mesh is shown in the lower panel. The low pressure contour represents the preprocessing vortex core (PVC) for the viscous mesh is noticeable compared with that of inviscid mesh. It confirms that the effect of the viscous grid should be part of the design parameters.
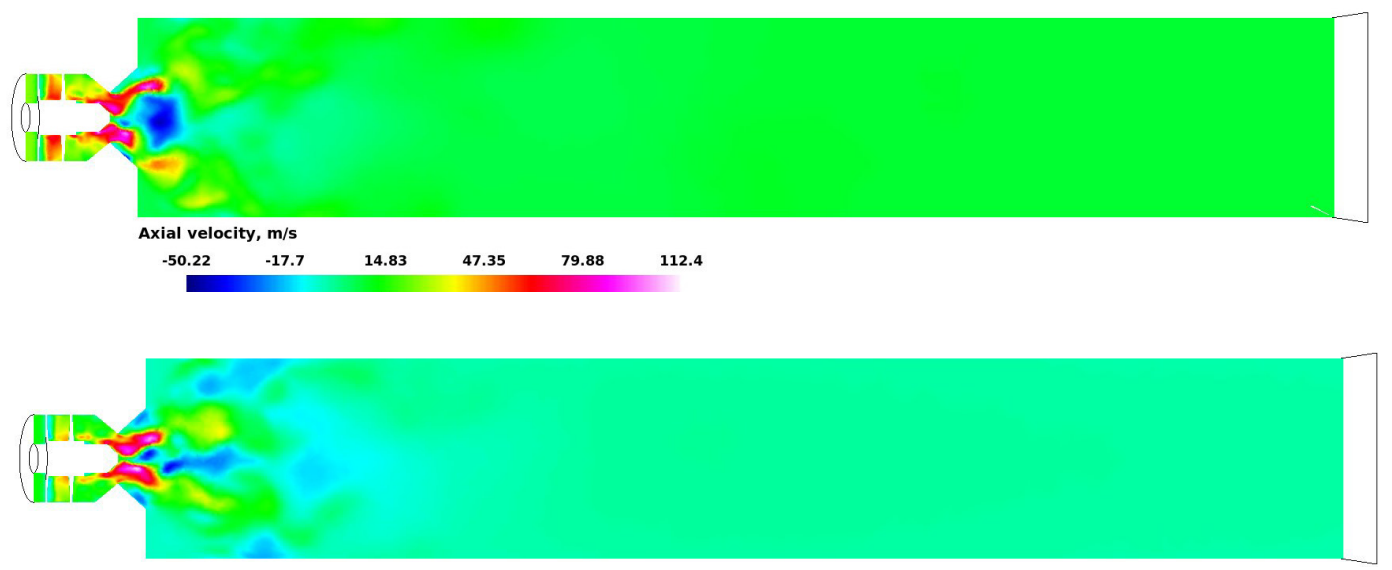

Figure 14.--Upper panel shows axial velocity contours with inviscid grid, lower panel with viscous grid.
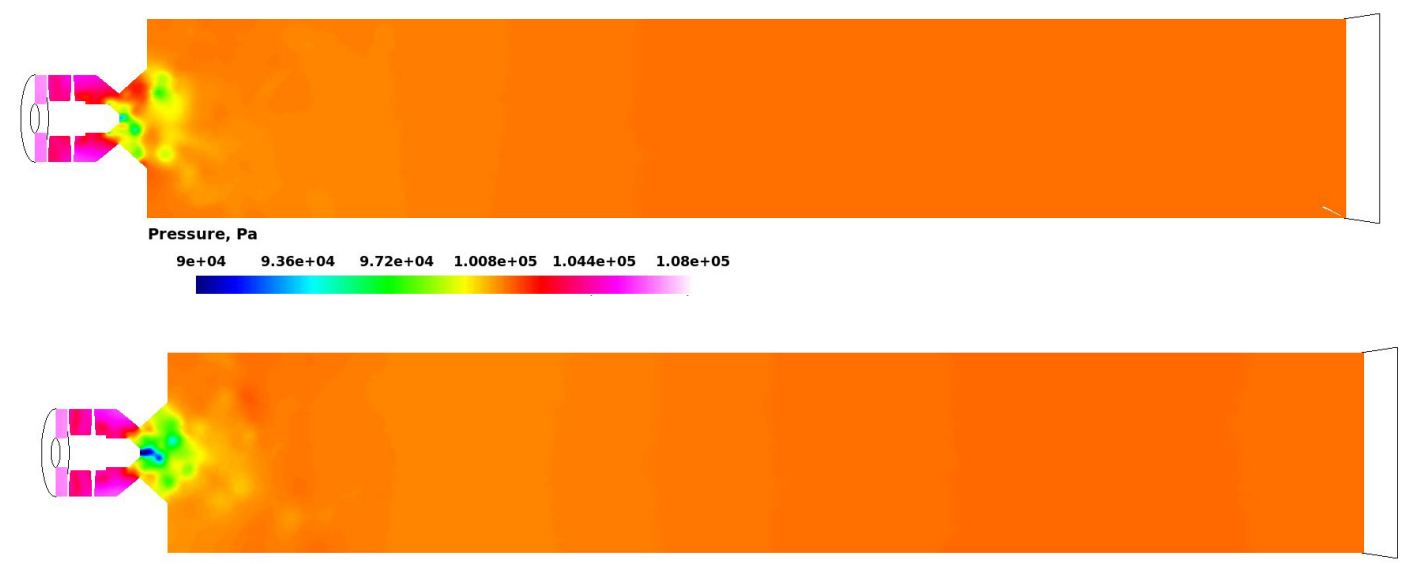

Figure 15.-Upper panel shows static pressure contours with inviscid grid, lower panel with viscous grid. 


\section{Reacting Case}

For reacting cases, beside the boundary conditions for the gaseous phase described above, the liquid fuel, $\mathrm{C} 12 \mathrm{H} 23$, is injected into the computational domain from a pressure swirl injector. The diameter of the orifice is $0.0006 \mathrm{~m}$. The fuel atomizer is set at a pressure $110 \mathrm{kPa}$ and delivers a flow rate of $0.025 \mathrm{~kg} /$ min. The spray has a $90^{\circ}$ spray angle which is the same as the converging-diverging venture attached to the swirler. An initial droplet size distribution is prescribed to provide the liquid fuel injection condition,

$$
\frac{d n}{n}=4.21 \times 10^{6}\left[\frac{d}{d_{32}}\right]^{3.5} e^{-16.98\left(\frac{d}{d_{32}}\right)^{0.4}} \frac{d d}{d_{32}}
$$

where $n$ is the total number of the droplets and $d n$ is the number of droplets in the size range between $d$ and $d+d d$. This correlation also requires the specification of Sauter mean diameter, $d_{32}$, and the number of droplet classes. The equivalence ratio computed from the gaseous and liquid inlet boundary conditions is about 0.72 . The adiabatic flame temperature is around $2100 \mathrm{~K}$. The chemical kinetics for the gaseous phase is represented by five reactions and seven species, which consist of $\mathrm{C} 12 \mathrm{H} 23, \mathrm{O}_{2}, \mathrm{CO}_{2}, \mathrm{CO}, \mathrm{H}_{2} \mathrm{O}$, $\mathrm{N} 2$ and NO.

TFNS results, obtained with the well-mixed combustion model for the meshes depicted in Figures 10 to 13 , are shown for axial velocity, static pressure, temperature and NO mass fraction in the center plane (i.e., $\mathrm{z}=0$ plane), respectively.

The temperature contours in Figure 16(d) indicates the flame near the exit of the swirler cup is not sustainable computed from Figure 10 mesh.

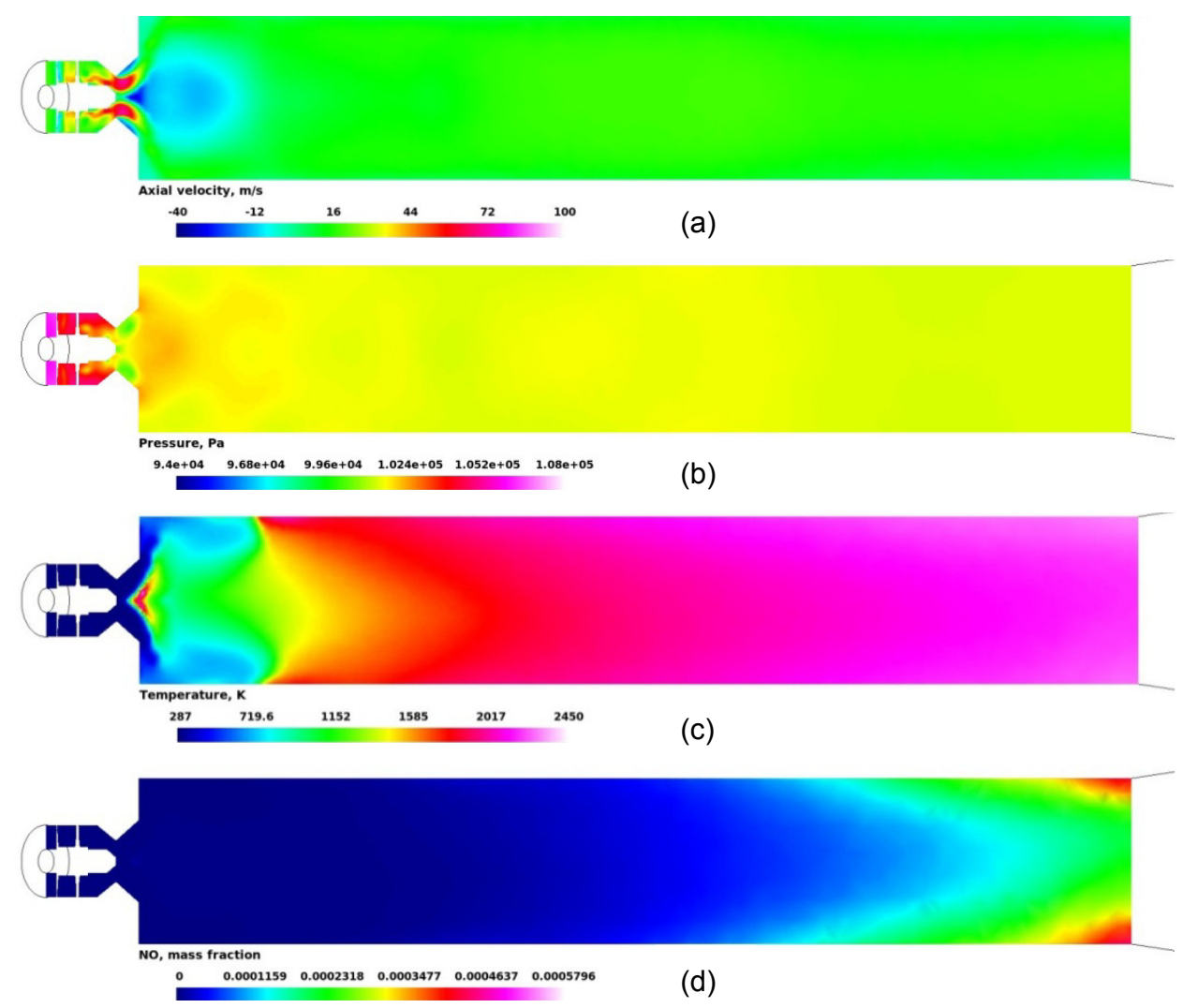

Figure 16.-Results from baseline mesh (Fig. 10): (a) axial velocity (b) pressure

(c) temperature (d) NO mass fraction. 
The temperature contours in Figure 17(d) indicates the flame near the exit of the swirler cup is sustainable computed from Figure 11 mesh though the region.
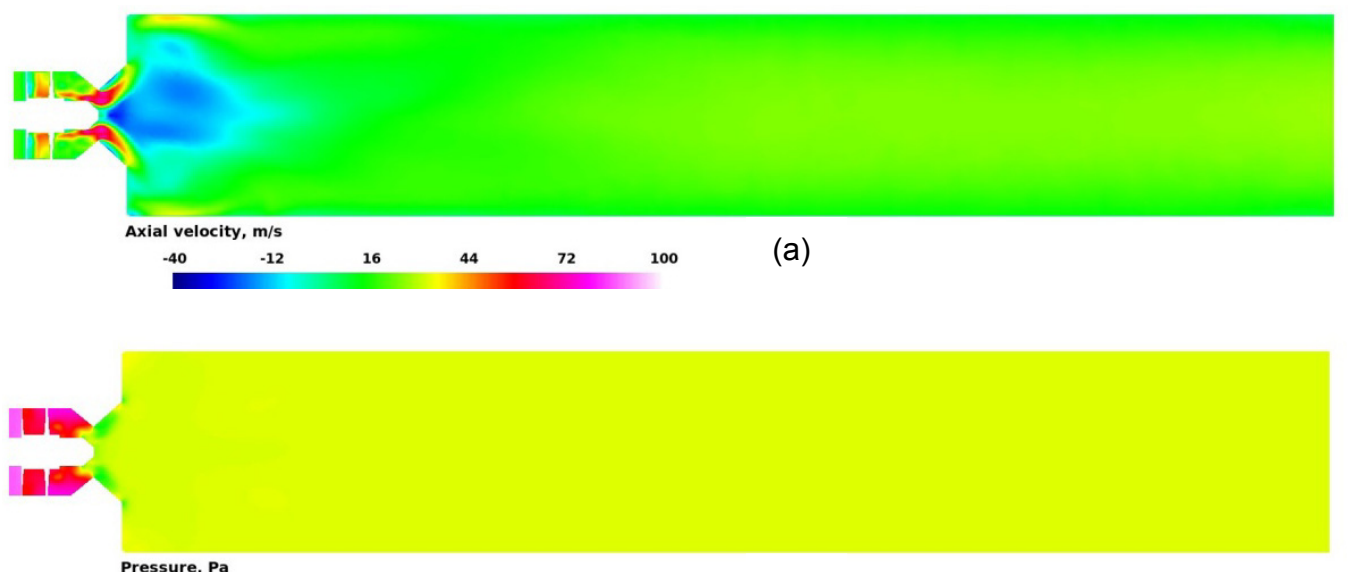

(b)

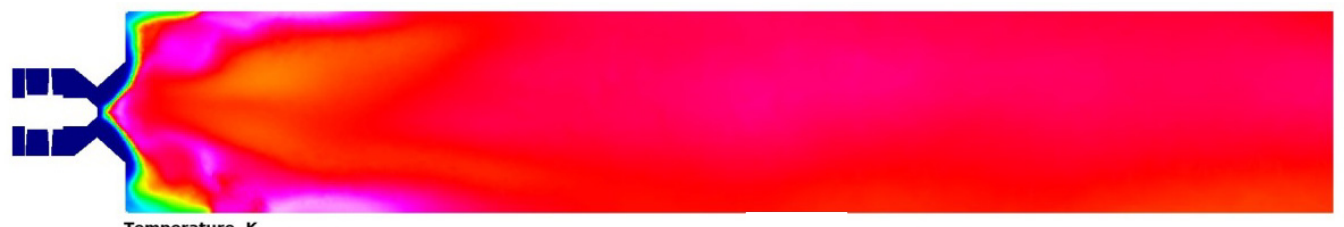

287

(c)

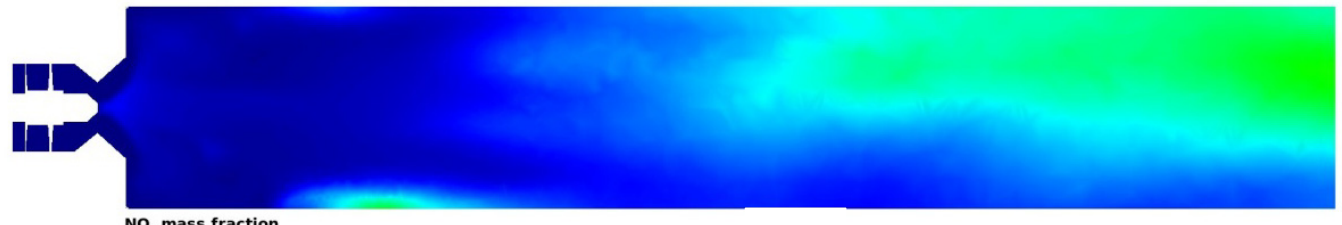

No, mass fraction

$\begin{array}{llllll}0.493 \mathrm{e}-05 & 2.985 \mathrm{e}-05 & 4.478 \mathrm{e}-05 & 5.97 \mathrm{e}-05 & 7.463 \mathrm{e}-05 & (\mathrm{~d})\end{array}$

Figure 17.-Results from mesh in Figure 11: (a) axial velocity (b) pressure (c) temperature (d) NO mass fraction. 
The temperature contours in Figure 18(d) indicates the flame near the exit of the swirler cup is also not sustainable computed from Figure 12 mesh. The region with higher temperature flame is about the same as that of Figure 10 mesh.
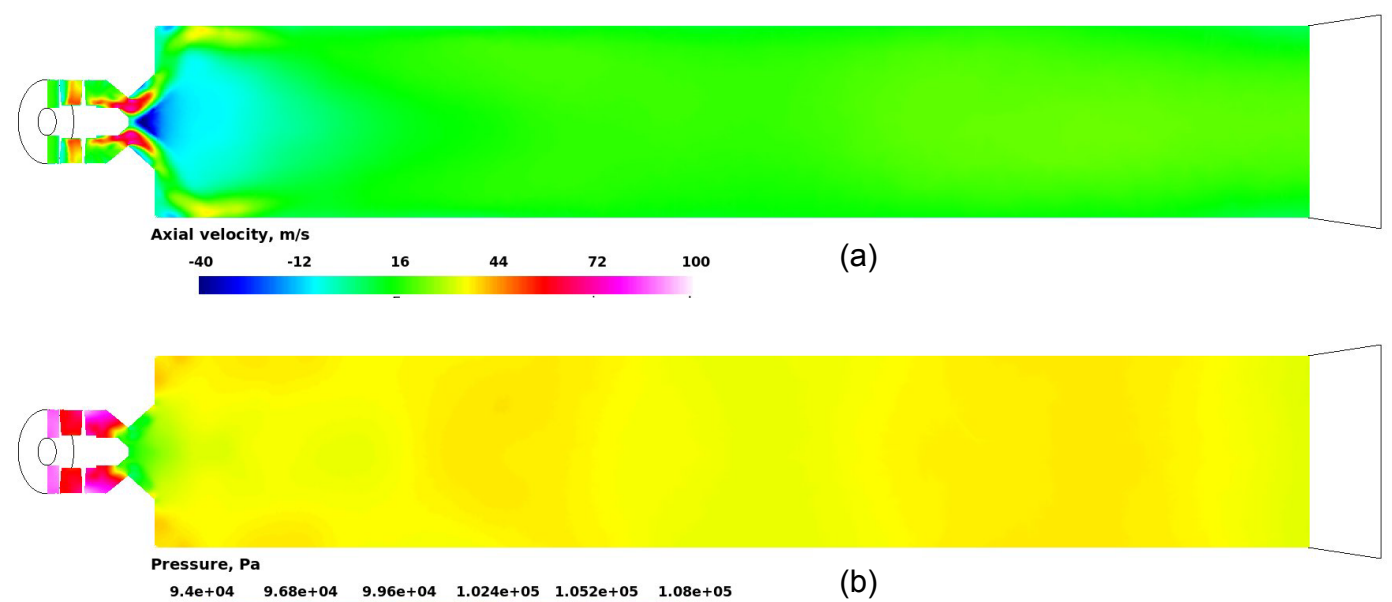

$\begin{array}{lllllll}9.4 e+04 & 9.68 e+04 & 9.96 e+04 & 1.024 e+05 & 1.052 e+05 & 1.08 e+05\end{array}$
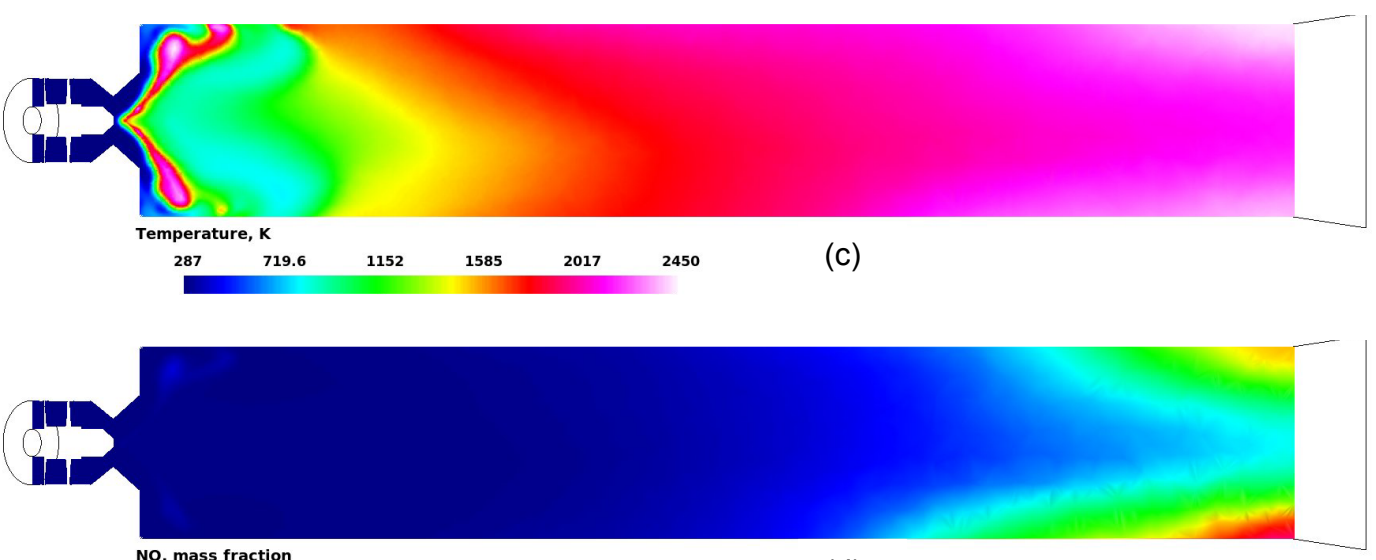

No, mass fraction

(d)

Figure 18.-Results from mesh in Figure 12: (a) axial velocity (b) pressure (c) temperature (d) NO mas fraction. 
The temperature contours in Figure 19(d) indicates the flame near the exit of the swirler cup is quite sustainable computed from Figure 13 mesh. The region with higher temperature flame is much larger than previous cases. It could be because that the mesh is refined much near the fuel injector. The number density of spray droplets in each cell near the fuel injector will be much smaller than other cases such that evaporation could be more effective.
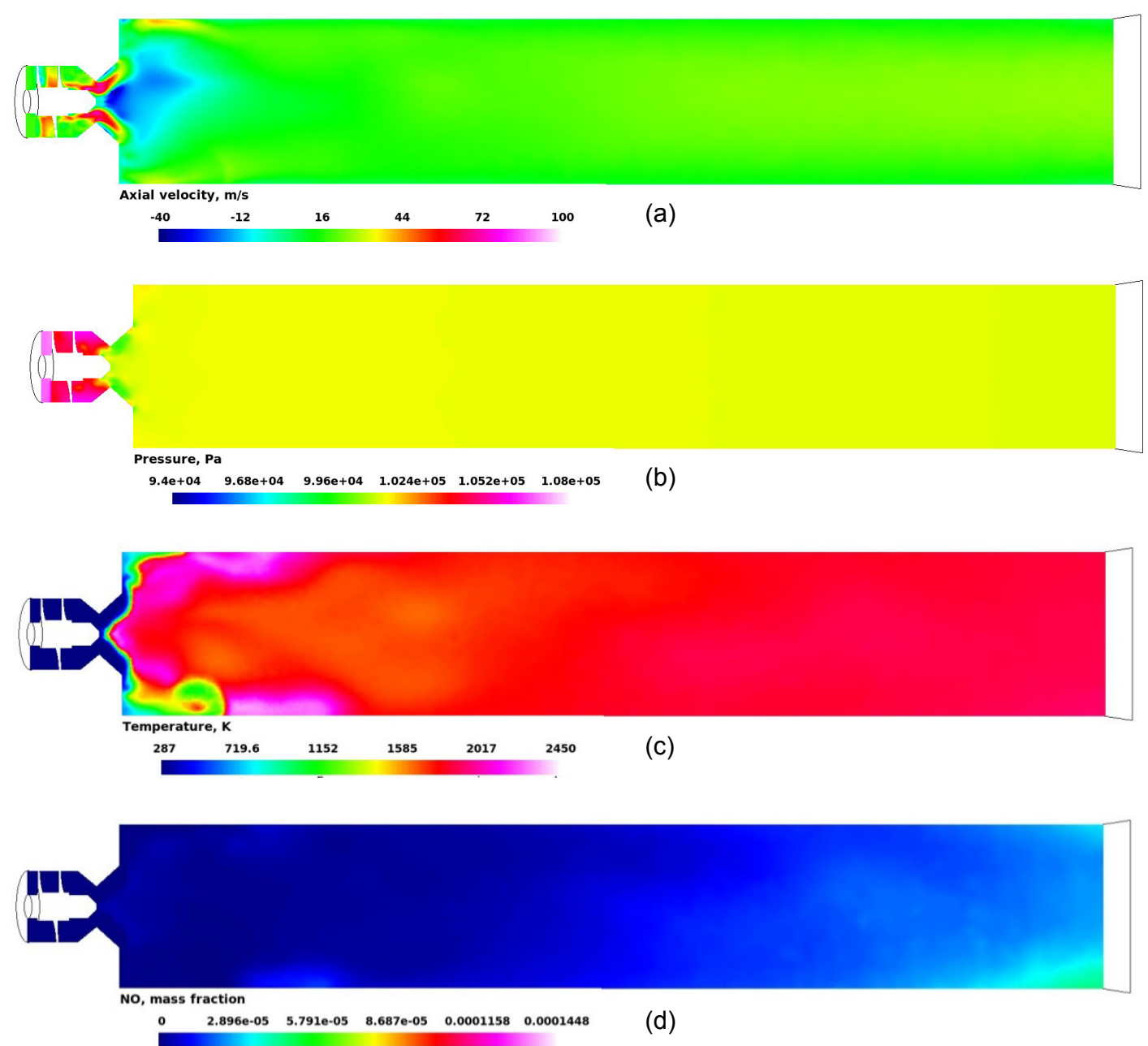

Figure 19.-Results from mesh in Figure 13: (a) axial velocity (b) pressure (c) temperature (d) NO mas fraction. 
The time-averaged centerline axial velocity and the centerline temperature are presented in Figures 20 and 21, along with the measured data. The discrepancy between the computed values and the experimental data are noticeable.

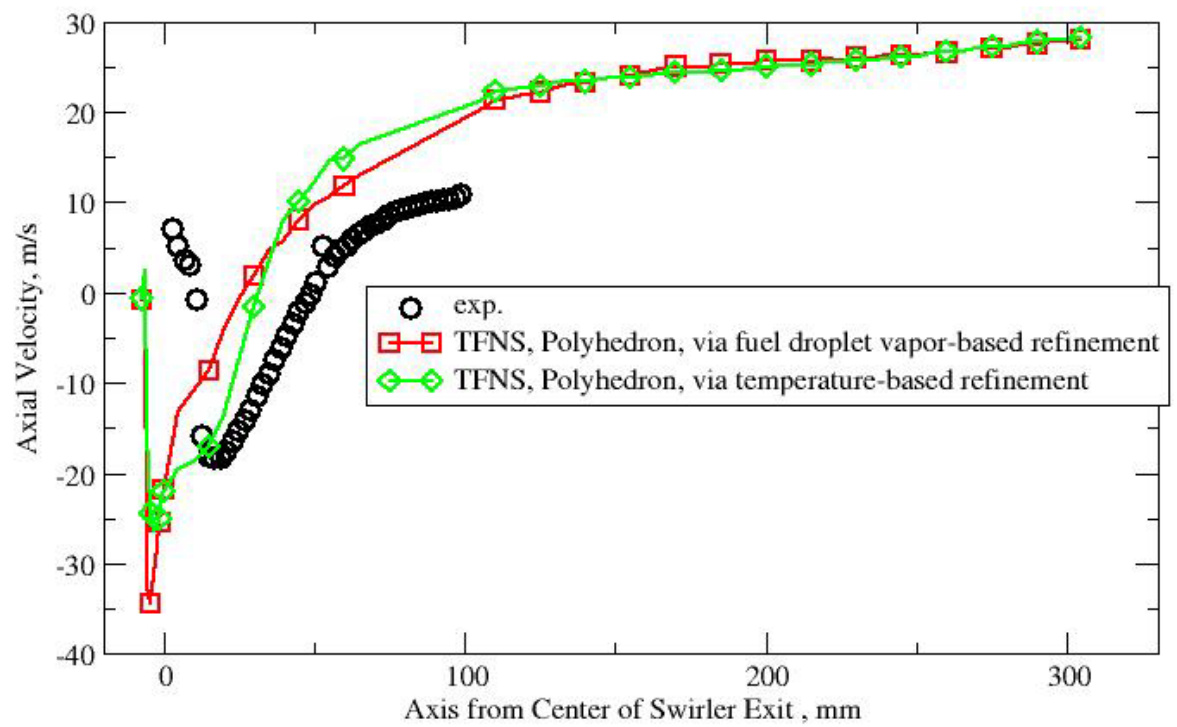

Figure 20.-Comparison of the mean axial velocity along the center line.

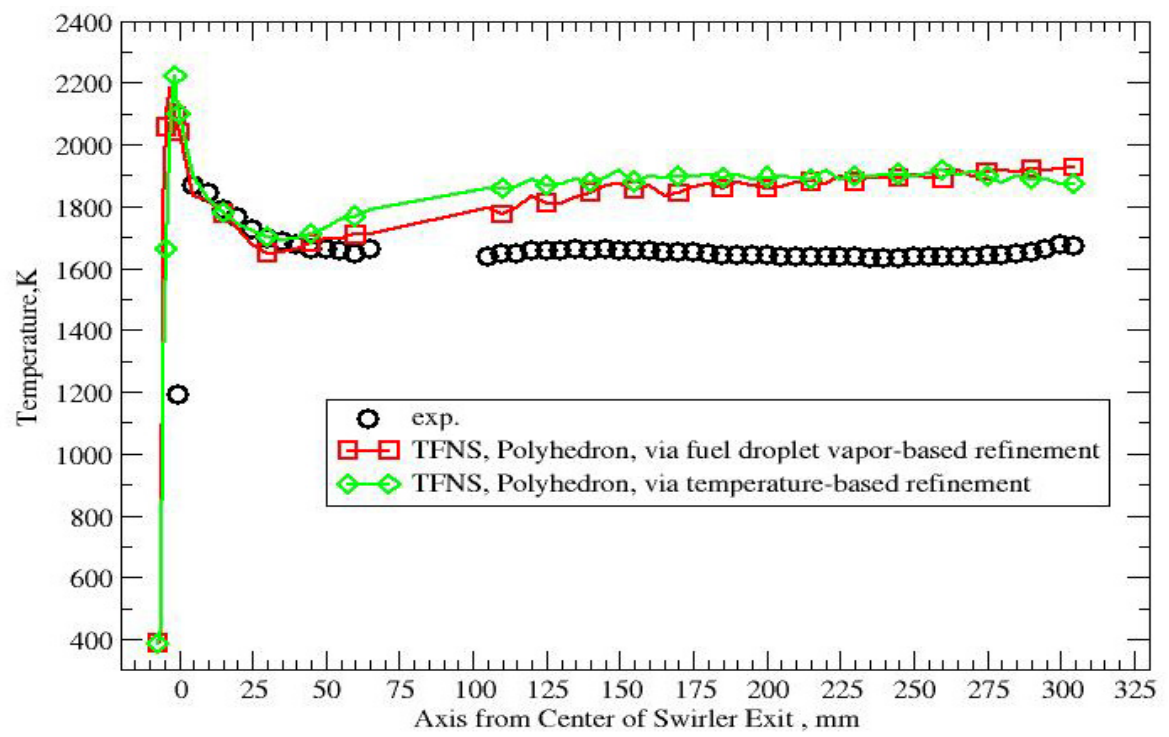

Figure 21.-Comparison of the mean temperature along the center line. 


\section{Concluding Remarks}

Capability of generating a thin-layer mesh for a given polyhedral mesh either with or without hanging-node elements is now implemented in a preliminary version of the OpenNCC, which is intended as the self-contained, releasable edition of the National Combustion Code (NCC). It is the second part of the adaptive mesh refinement option in OpenNCC. The thin-layer refinement consists of a radiated marching grid generation and a node-connectivity controlled mesh deforming technique.

A stand-alone single-element LDI combustor is selected for the demonstration. A viscous mesh is generated from an existing all-tetrahedron inviscid mesh. After a baseline viscous grid is built, three more refined grids are generated from the baseline grid. Their criterions are the temperature, the UHC mass fraction and the vapor of fuel droplets of the solutions.

It is observed that the temperature-based and fuel droplet vapor-based refined meshes resulted in more stable flame than other meshes.

\section{References}

1. Liu, N.-S., "Assessment and Improvement of Engineering Simulation for Multiphase Turbulent Combustion in a Lean Direct Injection Combustor," ISABE-2011-1108, 20 ${ }^{\text {th }}$ International Symposium on Air Breathing Engines, September 12-16, 2011, Gothenburg, Sweden.

2. Liu, N.-S., Shih, T.-H., and Wey, C.T., "Numerical Simulations of Two-Phase Reacting Flow in a Single-Element Lean Direct Injection (LDI) Combustor Using NCC," NASA/TM-2011-217031, July 2011.

3. Wey, T., and Liu, N.-S., "Simulation of a Single-Element Lean-Direct Injection Combustor Using Arbitrary Polyhedral Mesh," AIAA-2012-0204, 50 ${ }^{\text {th }}$ Aerospace Sciences Meeting and Exhibit January 9-12, 2012, Nashville, Tennessee.

4. Wey, T.C. and Liu, N.-S., "Simulation of a Single-Element Lean-Direct Injection Combustor Using a Polyhedral Mesh Derived from Hanging-Node Elements," AIAA-2013-0739, 51 ${ }^{\text {th }}$ AIAA ASM, Jan. 7-10, 2013, Grapevine, TX.

5. Wey, T.C., "The Applications of An Unstructured Grid Based Overset Grid Scheme to Applied Aerodynamics," $8^{\text {th }}$ International Meshing Roundtable, 1999. 



\begin{tabular}{|c|c|c|c|c|c|}
\hline \multicolumn{5}{|c|}{ REPORT DOCUMENTATION PAGE } & $\begin{array}{l}\text { Form Approved } \\
\text { OMB No. 0704-0188 }\end{array}$ \\
\hline \multicolumn{6}{|c|}{ 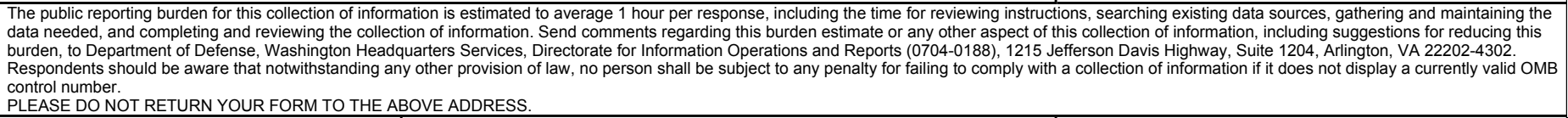 } \\
\hline \multicolumn{2}{|c|}{$\begin{array}{l}\text { 1. REPORT DATE (DD-MM-YYYY) } \\
01-03-2014\end{array}$} & \multicolumn{3}{|c|}{$\begin{array}{l}\text { 2. REPORT TYPE } \\
\text { Technical Memorandum }\end{array}$} & 3. DATES COVERED (From - To) \\
\hline \multirow{3}{*}{\multicolumn{5}{|c|}{$\begin{array}{l}\text { 4. TITLE AND SUBTITLE } \\
\text { Updates to Simulation of a Single-Element Lean-Direct Injection Combustor Using a } \\
\text { Polyhedral Mesh Derived From Hanging-Node Elements }\end{array}$}} & 5a. CONTRACT NUMBER \\
\hline & & & & & \begin{tabular}{|l} 
5b. GRANT NUMBER \\
\end{tabular} \\
\hline & & & & & 5c. PROGRAM ELEMENT NUMBER \\
\hline \multirow{3}{*}{\multicolumn{5}{|c|}{$\begin{array}{l}\text { 6. AUTHOR(S) } \\
\text { Wey, Changju, Thomas; Liu, Nan-Suey }\end{array}$}} & 5d. PROJECT NUMBER \\
\hline & & & & & 5e. TASK NUMBER \\
\hline & & & & & \begin{tabular}{|l|} 
5f. WORK UNIT NUMBER \\
WBS 794072.02.03.05.01
\end{tabular} \\
\hline \multicolumn{5}{|c|}{$\begin{array}{l}\text { 7. PERFORMING ORGANIZATION NAME(S) AND ADDRESS(ES) } \\
\text { National Aeronautics and Space Administration } \\
\text { John H. Glenn Research Center at Lewis Field } \\
\text { Cleveland, Ohio 44135-3191 }\end{array}$} & $\begin{array}{l}\text { 8. PERFORMING ORGANIZATION } \\
\text { REPORT NUMBER } \\
\text { E-18839 }\end{array}$ \\
\hline \multirow{2}{*}{\multicolumn{5}{|c|}{$\begin{array}{l}\text { 9. SPONSORING/MONITORING AGENCY NAME(S) AND ADDRESS(ES) } \\
\text { National Aeronautics and Space Administration } \\
\text { Washington, DC 20546-0001 }\end{array}$}} & $\begin{array}{l}\text { 10. SPONSORING/MONITOR'S } \\
\text { ACRONYM(S) } \\
\text { NASA }\end{array}$ \\
\hline & & & & & $\begin{array}{l}\text { 11. SPONSORING/MONITORING } \\
\text { REPORT NUMBER } \\
\text { NASA/TM-2014-218108 }\end{array}$ \\
\hline \multicolumn{6}{|c|}{$\begin{array}{l}\text { 12. DISTRIBUTION/AVAILABILITY STATEMENT } \\
\text { Unclassified-Unlimited } \\
\text { Subject Category: } 07 \\
\text { Available electronically at http://www.sti.nasa.gov } \\
\text { This publication is available from the NASA Center for AeroSpace Information, 443-757-5802 }\end{array}$} \\
\hline \multicolumn{6}{|c|}{ 13. SUPPLEMENTARY NOTES } \\
\hline \multicolumn{6}{|c|}{$\begin{array}{l}\text { 14. ABSTRACT } \\
\text { This paper summarizes the procedures of inserting a thin-layer mesh to existing inviscid polyhedral mesh either with or without hanging- } \\
\text { node elements as well as presents sample results from its applications to the numerical solution of a single-element LDI combustor using a } \\
\text { releasable edition of the National Combustion Code (NCC). }\end{array}$} \\
\hline \multicolumn{6}{|c|}{$\begin{array}{l}\text { 15. SUBJECT TERMS } \\
\text { Aircraft propulsion and power }\end{array}$} \\
\hline \multicolumn{3}{|c|}{ 16. SECURITY CLASSIFICATION OF: } & $\begin{array}{l}\text { 17. LIMITATION OF } \\
\text { ABSTRACT }\end{array}$ & $\begin{array}{l}\text { 18. NUMBER } \\
\text { OF }\end{array}$ & \begin{tabular}{|l|} 
19a. NAME OF RESPONSIBLE PERSON \\
STI Help Desk (email:help@sti.nasa.gov)
\end{tabular} \\
\hline $\begin{array}{l}\text { a. REPORT } \\
\text { U }\end{array}$ & \begin{tabular}{|l} 
b. ABSTRACT \\
U
\end{tabular} & \begin{tabular}{|l} 
C. THIS \\
PAGE \\
U
\end{tabular} & UU & $\begin{array}{l}\text { PAGES } \\
22\end{array}$ & $\begin{array}{l}\text { 19b. TELEPHONE NUMBER (include area code) } \\
443-757-5802\end{array}$ \\
\hline
\end{tabular}



